\title{
Congenital Infundibular Stenosis
}

National Cancer Institute

\section{Source}

National Cancer Institute. Congenital Infundibular Stenosis. NCI Thesaurus. Code C34961.

The obstruction of the right ventricular outflow tract that originates within the body of the right ventricle, that exists at the time of birth; it often occurs in association with other intracardiac anomalies. 